\title{
SCIENTIFIC HORIZONS
}

Journal homepage: https://sciencehorizon.com.ua

Scientific Horizons, 24(7), 81-89

UDC 658.8:659:33

DOI: $10.48077 /$ scihor.24(7).2021.81-89

\section{Coherence of Marketing Imperatives for Managing the Development of Socio-Economic Systems}

\author{
Liudmyla Tarasovych", Maryna Yaremova \\ Polissia National University \\ 10008, 7 Staryi Blvd., Zhytomyr, Ukraine
}

\section{Article's History:}

Received: 08.10.2021

Revised: 07.11.2021

Accepted: 10.12.2021

\section{Suggested Citation:}

Tarasovych, L., \& Yaremova, M. (2021). Coherence of marketing imperatives for managing the development of socio-economic systems. Scientific Horizons, 24(7), 81-89.

\begin{abstract}
At present, there is a reorientation of the current model of the market economy towards the principles of sustainable development. The process is accompanied by the implication of the marketing concept of managing socio-economic systems, the technology of which provides reasoning of the determined guidelines that must be adhered to. In this context, the coherence of marketing imperatives is a determinant of ensuring the development of socio-economic systems, whereas the marketing-imperative approach should be considered one of the levers of sustainable economic development. Therefore, the purpose of the study is a complex substantiation of the theoretical and methodological content of marketing imperatives, the interpretation of their coherent influence on the management of socioeconomic systems. The methodological basis of the study is an integrated combination of general scientific methods of systematic cognition and possibilities of application of specific methodological approaches to solving problems and verification of the formulated study hypothesis; the methods include monographic, hypothetical prediction, abstract-logical, induction and deduction, historical and economic, structural-functional analysis, abstraction and content analysis, construction of concepts and categories, graphical and tabular. The study provides insights into the special features of the evolution of the etymological essence of the imperative in the context of transformations of socio-economic systems; the essence of marketing imperatives in view of marketing ideology is substantiated; the mechanism of transformation of objectives into imperatives in achieving the goal of socio-economic system is developed; the necessity of the implication of the marketing-imperative approach in sustainable economic development is proved. The practical value of the study consists in the scientific substantiation of the theoretical and methodological content of marketing imperatives, the specification of their coherent impact on the management of socio-economic systems. Further studies are aimed at developing criteria for measurement, assessment, and interpretation of the effect after the implementation of marketing imperatives with subsequent testing of results
\end{abstract}

Keywords: marketing imperative, marketing concept, marketing objectives, socio-economic system, development management, transformation 


\section{INTRODUCTION}

Modern stage of the development of the national economic system, along with quantitative changes in its key parameters, is characterised by: firstly, considerable qualitative transformations associated with the growth of market uncertainty, the aggravation of competition, including in the international arena; secondly, the increased orientation of production on the needs of consumers, maximum consideration and satisfaction of their needs and interests (meeting consumer demand is a priority for business); thirdly, the acceleration of the pace of scientific and technological progress, innovatisation as a predictive idea of the development of socio-economic phenomena and processes, which causes the emergence of new branches, technologies, industries, reduction of the life cycle of goods (services); fourth, digitalisation of business processes and emphasis on new logistics approaches to the organisation of basic models for product (service) promotion; fifth, strengthening of the requirements for the quality and prestige of the product, trademark, reputation and image of the producer, etc. Under such circumstances, the need is exacerbated and the paramount importance of marketing tools and technologies for the development and implementation of innovative models of economic development in general and in terms of its individual segments is emphasised.

The focus of modern researchers on the priority of marketing approaches to managing socio-economic systems is caused by the growing need to raise the role of market levers and mechanisms in the context of a globally oriented mainstream of social development. The current emphasis on the use of conventional management concepts is shifting towards the privileged principles of sustainable development management. Confirmation of this is that the mission of the National Economic Strategy until 2030 is defined as "creating opportunities for the fulfilment of the existing geographical, resource, and human potential to ensure the well-being, self-fulfilment, security, and freedoms of every citizen of Ukraine through innovative economic growth" [1]. In the implementation of this vision, a prominent place is given to the use of a marketing and imperative platform for forming concepts for managing this process with a focus on challenges of the global economic space and sustainable development goals.

Currently, the imperative principle is increasingly appearing in the discourse of researchers of various interest spheres of scientific schools and trends. The essence of the imperative is explained by philosophers, linguists, lawyers, managers, economists, marketers, environmentalists, technologists, sociologists, historians, and other specialists, with an emphasis on individual professional provisions. That is, the "imperative" principle is increasingly used in relation to the basics of human life in almost all spheres of its existence. The outlined facts stimulate development and are simultaneously determined by the transformations of social phenomena and processes, that is, their binary content is emphasised - compliance with Imperative norms ensures development. In turn, in economic theory, development is considered mainly as a process that results in a change in the quality of the developing object, a transition from one qualitative state to another - the highest. It is well known that development as an economic category has such characteristic features as movement, process, change, and time. In addition, the development of any system takes on a systemic character due to such properties as irreversibility, orientation, and regularity. According to the opinions and approaches of modern researchers, development is "evolution with a directed trajectory and a linear causal relationship" [2, p. 19]. Therefore, there is reason to assert that imperatives are an indispensable component of mechanisms for managing socio-economic systems and the prerogative of their development.

The purpose of this study is a substantiation of the theoretical and methodological content of marketing imperatives, a definition of the level of their coherent impact on the management of the development of socioeconomic systems. The key tasks are as follows:

1) to highlight the features of the evolution of the etymological essence of the imperative in the conditions of market transformations;

2) to characterise the content of marketing imperatives in view of marketing ideology from the standpoint of transformation of goals into imperatives in achieving the goal of development of the socio-economic system;

3) to prove the need to apply the marketing-imperative approach in the sustainable economic development.

\section{LITERATURE REVIEW}

The principle of the imperative is considered to be applied mainly in the field of practical philosophy. The fundamental analysis of its etymological essence is conducted in the studies of the well-known researcher I. Kant, "Groundwork of the Metaphysics of Morals" (1785) and "Critique of Practical Reason", (1788), which highlight "...cognitive capabilities of the mind, in isolation from knowledge obtained empirically, that is, through experience" [3]. The imperative, according to the researcher, is "a rule containing objective compulsion to act of a certain kind; it is the relation of human freedom to the laws of morality" [3]. That is, the studies of I. Kant are based on the examination of imperatives in the philosophical cognition of man. I. Kant divides all imperatives into two groups: a) categorical (undeniable, unprecedented moral precepts "on the proper behaviour of a person as an intelligent being with free will; the execution of this order is absolutely necessary, regardless of whether a person receives benefits for oneself as a result)" [3] and b) hypothetical (relatively variable imperatives, which largely depend on various factors; certain requirements that must be observed as necessary conditions for achieving 
the goals set; it is not an end in itself and it only acts as a means achieving the goal) [3].

In the new dictionary of foreign words, imperative (lat. imperativus - mandatory) is considered as 1) urgent demand, behaviour; 2) imperative mood [4, p. 257]. In the online dictionary of the Ukrainian language, this definition is presented as an unconditional, categorical demand, command, order [5, p. 20]. In a well-known American dictionary Merriam-Webster, the imperative a) "expresses the will and influences the behaviour of another"; b) "expresses pleas, persuasions, necessity"; c) "has the ability to restrain, control" [6]. That is, the majority of modern dictionaries emphasise the persistence or requirement to comply with the imperative, the mandatory method of compliance.

Modern researchers use the principle of imperative mainly as a completely understandable phenomenon without detailing its deep essence and features of the application in the relevant fields or industries. In identifying existing developments on the essence of the "imperative" in the economic sphere, it should be noted that quite often Ukrainian researchers consider the imperatives of economic development: firstly, as individual phenomena (sustainable economic growth, social and environmental stability, innovative transformations, creative management decisions, digitalisation of business, etc.) [7-9]; secondly, the imperatives of individual areas or branches of activity (strategic, economic, institutional, geo-economic, financial, environmental, social, European integration, convergent, humanistic, creative, cultural, tourist, technological, informational, cultural, social) [1012]; thirdly, as absolutely diverse, often unrelated aspects with synonymous substantiation, in particular, the identification of imperatives with: a) determinants (focuses on components, causes, conditions of influence) [13-15]; b) factors, drivers (emphasise the sources of influence) [16; 17]; c) opportunities, areas, features, trends, manifestations (options for solving problems are outlined) [15; 18].

\section{METHODOLOGY}

The theoretical and methodological platform for conducting this research was an organic combination of generally accepted provisions and principles of economic research, fundamental postulates of economic theory, the concepts of the theory of managing the development of socio-economic phenomena and processes with the appropriate study of the possibilities of applying specific methodological approaches to in-depth argumentation and solving tasks and verifying the formulated research hypothesis, the content of which is that the introduction of marketing imperatives of managing socio-economic systems will ensure their sustainable development. In addition, the research methodology is supplemented by an in-depth study of the scientific heritage of Ukrainian and foreign researchers, whose research interests are the problems of forming imperatives of economic development and highlighting the place and role of the marketing concept in this process.

The methodological tools of the research portfolio are formed from general scientific and special scientific methods. Upon using methodological constructions of the system approach, the components of the "spiral model" of society development (immanent effect of the imperative $\rightarrow$ identification of advantages, disadvantages, threats, opportunities, risks $\rightarrow$ actualisation of the need for transformation $\rightarrow$ development of a qualitatively new imperative) in the plane of proliferation and their system interaction with the focus on the features of the life cycle of the imperative and the time interval of its action are characterised. A hypothetical prediction allowed characterising the potential opportunities and advantages of orienting the development of socio-economic systems in the area of activating mechanisms and technologies for managing economic phenomena using marketing tools, its implementation in all spheres of the economy.

The study of the problem of development of marketing imperatives for managing the development of socio-economic systems is conducted in an organic combination of historical aspects of this phenomenon with the logic of transformation of this process and abstract configuration of expected results. The abstract-logical method is applied to generalise scientific results, formulate relevant conclusions through in-depth cognition of managing the development of socio-economic systems on a marketing basis. This approach was based on the fact that if the implementation of marketing imperatives in the practical plane of managing the development of socio-economic systems can be learned empirically, the meaning of this phenomenon - only through logical thinking. The historical and economic method was used to highlight the features of the evolution of the etymological essence of the imperative in the context of transformations of market-oriented economic systems. The results of the study on the etymological essence of marketing imperatives are compared based on the method of comparative analysis. The induction and deduction are used for in-depth study and systematisation of the basic provisions of the theory of marketing management through their extrapolation into the plane of managing the development of socio-economic systems at various hierarchical levels (micro-, macro-, meso-), their systematisation with subsequent differentiation of scientific approaches to understanding the essence of imperatives, their classification in the context of various scientific schools and trends. The monographic method is used for in-depth research of the problems posed and substantiation of the possibilities of involving individual marketing tools and technologies in the management process. The structural and functional analysis identifies the components and processes of creating an institutional environment for the implementation of marketing imperatives in managing the development of socio-economic systems. 
During the study, the following methods were also used: abstraction and content analysis to deepen the content of marketing imperatives in view of marketing ideology and prove the need to implement the principle of a marketing-imperative approach to the study of socio-economic units in the establishment and development of a market economy. The method of constructing concepts and categories is applied for the purpose of critical analysis of existing ones and formulation of the author's vision regarding the definition of the principle of "marketing imperative". The mechanism of transformation of goals into imperatives in achieving the goal of the socio-economic system with the appropriate formulation of the vision, concept, and strategy is substantiated using the transformational analysis. Upon using tabular and graphical methods, a visual interpretation of the obtained research results is conducted for a better perception of the presented research results.

\section{RESULTS AND DISCUSSION}

The implication of the imperative in the establishment and development of socio-economic systems

The methodological perspective of the study of the development is associated with positive changes in the object under study, the processes of improvement, acquisition of new qualities and properties, the transition from one qualitative state to another - higher, characterised by the opposite of the invariance of being [2]. That is, there is a transformation of quantitative signs of development into qualitative ones with corresponding changes in individual elements of the system, directly in the production system and, as a result, in structural and functional relations. Coherence of marketing imperatives in this regard should be considered a necessary condition for ensuring development. Modern mechanisms for ensuring socio-economic well-being and growth are accompanied by the establishment of self-regulatory relationships and their development through the "spiral" character of this phenomenon [18, p. 23]. This phenomenon occurs due to the fact that after achieving maximum efficiency, under certain circumstances, the next stage is when the imbalance between the existing imperative norm and the environment transformed in the process of development increases over a certain period. As a result, there is a need for a qualitative update of the previous content of the imperative, considering the new initial provisions, to ensure effective interaction in a society designed to ensure socio-economic development. This process takes on the character of proliferation - a continuous increase of new rules and norms of socio-economic interaction of individuals based on those that have already completed their development [4, p. 499; 20]. Thus, considering the above provisions, Figure 1 generalises the model of the establishment of imperatives of socio-economic system development.

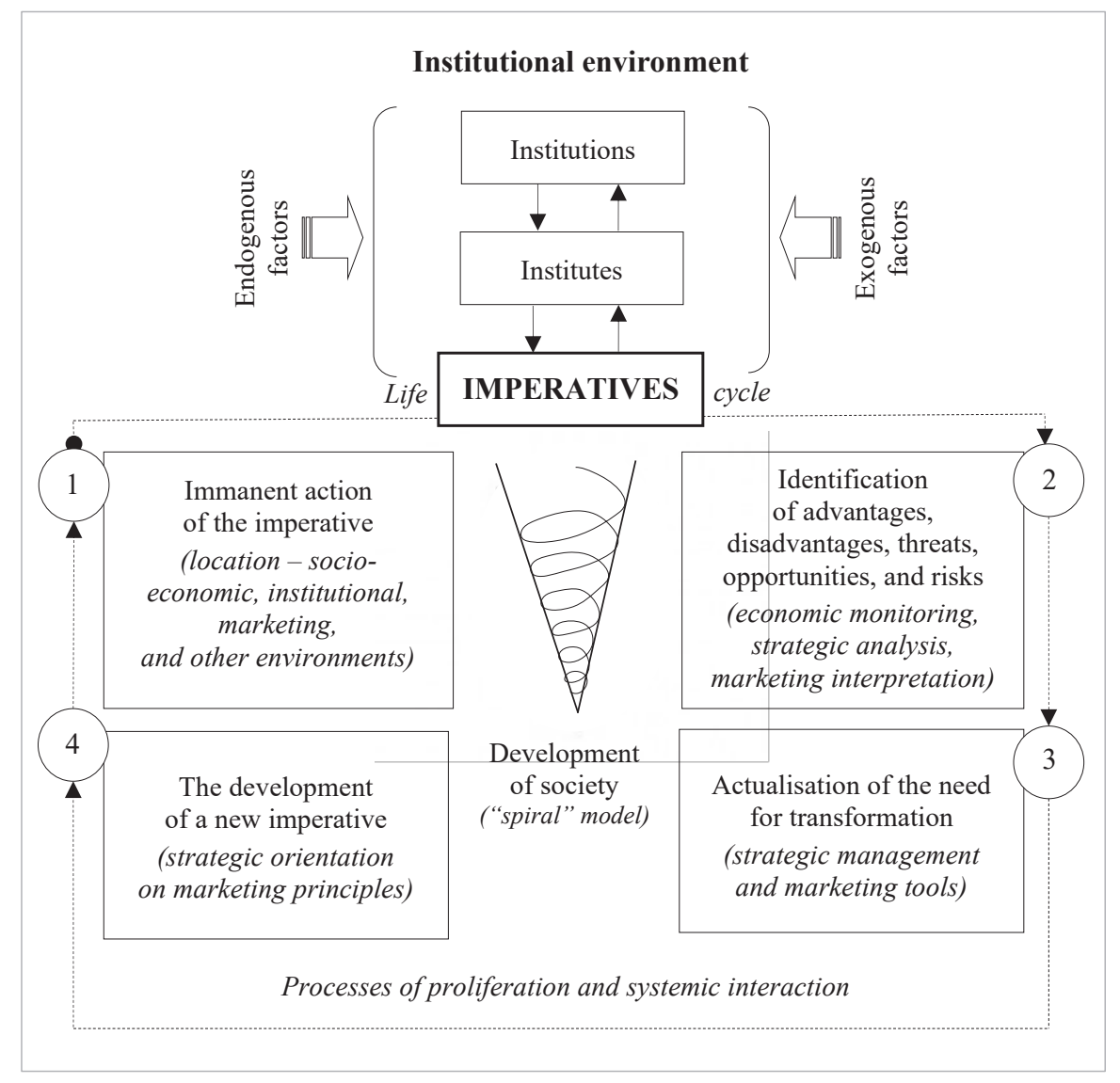

Figure 1. Establishment of imperatives for the development of socio-economic systems Source: developed by the authors based on the studies [17; 19, p. 225] 


\section{Explication of marketing imperatives: Convergence and divergence of scientific approaches}

In one of the modern dictionaries, the imperative is interpreted as "a principle that has the character of an unconditional duty and is based on deep moral and ethical beliefs of a person, which as a result makes a formalised moral or ethical social norm as effective as possible" [21]. This aspect, according to M. Ilina, and Y. Shpyliova, is a key for identifying the differences between formal and informal social rules and, in fact, imperatives [10, p. 222]. Researchers claim that with this approach the relationship between the definitions of "institution", "institute", and "imperative" is established, which occurs mainly in the case of identifying mandatory and formal norms while simultaneously delineating their boundaries and criteria. Admittedly, these concepts are not identical, despite their functional and evolutionary similarity. This approach lies in the fact that the institution as a certain form of organisation, regulation of public life, activities and behaviour of people gives an impetus to the establishment and further development of the institution as a characteristic organisational and structured form of interaction of individuals in society [19, p. 22]. As a result, the institution based on generally accepted customs and considering the probability of its perception by society forms an imperative that should ensure the necessary regulation and coordination of relations in a certain institutional environment [10, p. 222; 11]. For their part, national researchers define institutional environment as "a clear ordered set of institutions that determine the framework conditions for the functioning and development of economic entities" [10, p. 223], or "infrastructure that is designed to contribute to efficient production activities, rapid commodity exchange, the development of a positive image of the enterprise, and the use of innovative developments in economic activities" [22, p. 284], etc.

As for the classification of imperatives, they are most often divided into a) imperatives of direct influence (direct action); b) intermediate imperatives (adaptive action); c) hidden imperatives (indirect action). It is important to focus on the imperatives of direct action, which, primarily, should include economic, political, environmental, and social. Economic imperatives are often considered to be the statement that the national economic system should be "efficient, competitive, and, at the same time, socially oriented, resource- and energy-efficient, environmentally stable, etc." [10, p. 224]. That is, such imperatives are based on mandatory requirements because otherwise there will be irreversible processes of social importance that are not desirable in the creation of a certain course of development of the economic system.

It is well known that "the laws and regularities of economic management are objective and do not depend on the will and consciousness of people. Their effect is manifested only in human activity, depending on how fully the requirements of objective laws are considered" [23]. In this sense, the term "marketing imperative" is becoming increasingly important, because, as already noted, under market conditions, the role of marketing institutions in the management of socio-economic phenomena and processes increases. In view of this, it can be argued that its content, in relation to the fundamental nature of the requirement to perform specific actions, is expanded due to marketing specific features or the field of research. In this regard, it becomes clear that when referring to marketing imperatives, it is necessary to apply the tools of marketing - a branch of economics that studies the theory and methodology of marketing [4, p. 367].

In the studies of foreign researchers, most often attention is focused, firstly, on the substantiation of marketing imperatives as tools for responding to the consequences of the globalisation of marketing, that is, expanding its framework boundaries and promotion in the international environment $[24 ; 26]$; secondly, on highlighting the principles of strategic marketing as target indicators for defining the imperatives of the development of socio-economic phenomena and processes [25]; thirdly, on the exposure of marketing technologies for the establishment and development of business [27].

R. Griffin and M. Pastey in the famous study named International Business consider three key marketing imperatives in the context of business globalisation, namely: 1) the use of key competence of the enterprise (that is, the possibility of wider application of those competencies (strengths, competitive advantages) that were most developed in the national market); 2) penetration of the company into new markets (in the conditions of a fully formed national market, in which the opportunities for further development and profit generation narrow); 3) the need to compete in own industry (to maintain existing competitive advantages and identify new ones) [24].

American researchers M. Czinkota, I. Ronkainen, J. Tarrant, etc., in their study The Global Marketing Imperative, 1995, thoroughly cover the mission of marketing imperatives as a determinant of competition management at the international level, emphasising the role of strategic marketing tools in promoting business to the global environment [26]. Researchers have detailed marketing steps to ensure the success of business structures in the international arena.

C. Churchwell, based on the scientific statements of K. Bartlett and S. Goshal, suggests reflecting the following marketing imperatives in the activities of a modern enterprise: "1) it is necessary to remain effective on a global scale and maintain competitiveness, integrating different types of activities and coordinating the work of labour resources in different countries of the world; 2) it is necessary to respond sensitively to the tastes of customers and the requirements of governments; 3) a modern manager should see the world not only as a set of national markets but as a source of information, knowledge, and skills, which, in turn, are key resources for ensuring the development of innovations and their implementation all over the world" [25]. 
Research has established that in Ukrainian studies, the coverage of the essence of marketing imperatives is not given due attention. Therewith, adherents of modern marketing emphasise the need to strengthen the marketing orientation of technologies for managing socioeconomic phenomena and processes [27-29]. A review of papers on this subject suggests that most researchers associate this principle mainly with the features of marketing activities of business entities, stating that its structuring is based on MarTech, and technologisation of marketing activity is considered as an objective requirement of the present and a tool for improving the organisation and clarity of the work performed, a clear substantiation for the stages of its implementation, techniques and actions aimed at achieving marketing goals [9, p. 45].

Marketing technologies, in the conditions of effective support of the development and implementation of marketing solutions for the coordination of interests of business entities, consumers, and society in general, contribute to solving problems not only in the production but also in the management of a specific sphere of socioeconomic relations. The most common modern marketing technologies, the effectiveness of which is proven in practice, are the following: merchandising; direct, network, viral, guerrilla marketing; cross-marketing; product placement; Internet marketing; SEO; SMM and SMO; branding; social marketing technology, etc. The expediency of using a particular technology, or a combination of them, is determined by the tasks set within the framework of achieving specific goals.

If the mission defines the business philosophy, imperatives are positioned as real goals, the effect of achieving which can be quantified. The above refers to, for example, such goals as business expansion, improving the quality of products (services), high level of service, image growth, brand promotion, etc. Evidently, the established goals are not imperatives in their content, but they are transformed into imperatives when the management decision states the need to achieve these goals in a mandatory manner (Fig. 2).

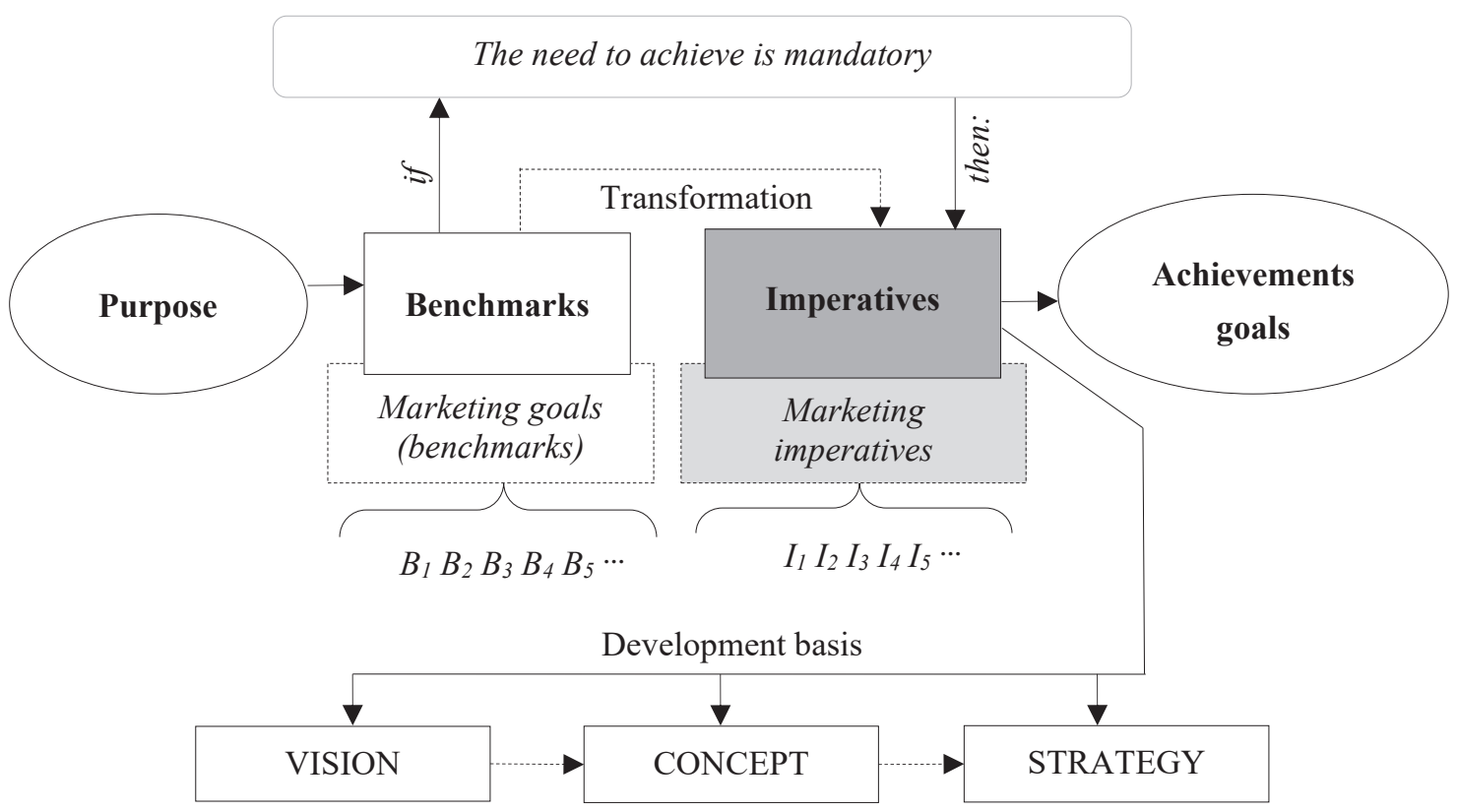

Figure 2. Mechanism of transformation of "benchmarks" into "imperatives" in achieving the goal of the socio-economic system

Source: authors' own research

Summarising the above, it is proposed to consider marketing imperatives as benchmarks (marketing goals) that must be followed in managing the economy to ensure its development on a marketing basis.

\section{Marketing imperatives - vectors of modern business development}

It is worth noting the importance of the research results of N. Capon (USA), V. Kolchanov (Russia), and J.McHulbert (USA), which distinguish six generalised marketing imperatives, which, in fact, allow modelling the vector of scientific search on the studied problems: 1) identify and recommend markets to work with; 2) identify market segments and focus on them; 3 ) choose a strategic area and positioning; 4) develop marketing proposals (marketing complex); 5) ensure consistency with other functions (support of project development and implementation processes); 6) monitor implementation and control results [31]. Details of these imperatives in terms of their practical implementation are presented in the book by N. Capon The Virgin Marketer, which outlines the key marketing principles: selectivity and concentration; values for the consumer; competitive advantage; integration [30]. 
Indisputable scientific value from a theoretical, methodological, and practical standpoint is represented by annual thorough research conducted by the world's leading marketing companies. The importance of the results of sociometric observations conducted by the agency Merkle should be emphasised [32]. The company positions marketing imperatives from the perspective of strategic vectors of modern business development at various levels of object-subject relations. The credibility of the results presented in social networks is characterised by uniqueness, constructiveness, relevance, and accessibility of perception of the information resource presented on the platform based on the involvement of various marketing technologies (Table 1 ).

Table 1. Content of marketing imperatives of modern business (according to research by Merkle marketing agency)

\begin{tabular}{|c|c|}
\hline Year & Key orientation \\
\hline \multirow[b]{2}{*}{2017} & Building a digital marketing strategy to predict the prospects of retail \\
\hline & $\begin{array}{l}\text { Imperative } 1 . \text { Using digital marketing to improve customer interaction. } \\
\text { Imperative } 2 \text {. Using multi-channel features. } \\
\text { Imperative } 3 \text {. Using data to form a digital strategy }\end{array}$ \\
\hline \multirow[b]{2}{*}{2018} & Strengthening of email-marketing \\
\hline & $\begin{array}{l}\text { Imperative } 1 \text {. Centralised customer data to improve access and promote growth. } \\
\text { Imperative } 2 \text {. Construction of a map in real time before the implementation of the solution. } \\
\text { Imperative } 3 . \text { Involving IT in vendor evaluation }\end{array}$ \\
\hline \multirow[b]{2}{*}{2019} & Integrated marketing strategy focused on people \\
\hline & $\begin{array}{l}\text { Imperative 1. Integration of the client's strategy. } \\
\text { Imperative } 2 \text {. Integration of one's own technology stack. } \\
\text { Imperative } 3 \text {. Integration of one's own execution }\end{array}$ \\
\hline \multirow[b]{2}{*}{2020} & Hyper-personalisation and customer interaction \\
\hline & $\begin{array}{l}\text { Imperative 1. Ensuring complete customer experience. } \\
\text { Imperative 2. Personal ownership (personal brand) as a key business advantage. } \\
\text { Imperative } 3 \text {. Ensuring agility through strategic search }\end{array}$ \\
\hline \multirow[b]{2}{*}{2021} & Customer experience \\
\hline & $\begin{array}{l}\text { Imperative 1. Data transformation. } \\
\text { Imperative 2. Digital transformation. } \\
\text { Imperative 3. Adaptive organisation }\end{array}$ \\
\hline
\end{tabular}

Source: developed by the authors based on the studies [32-34]

The results of summarising the information published on the website [32] indicate a systematic innovation-oriented update of targeted marketing imperatives for business process development, which allows stakeholders to gain personalised opportunities and skills to improve the effectiveness of management processes in rapidly changing external conditions. Notably, considering the proposed imperative substantiation for managing the development of socio-economic systems is an indisputable tool for activating the management system at various levels of hierarchical influence.

\section{CONCLUSIONS}

1. In modern research on management, economics, and marketing, imperatives are laid down as the basis for setting the mission and goal of developing socio-economic systems and are considered at different levels (micro-, meso-, macro-), which, accordingly, causes differences in their content, orientation, manifestation, evaluation parameters, interpretation of effects, etc. The potential effect, if the corresponding marketing imperative is met, is achieved in immanent conditions of the socio-economic system, the level of influence of factors of its marketing endo- and exogenous habitats, and proliferation of the imperative.

2. The essence of marketing imperatives in view of marketing ideology is covered through their consideration as benchmarks (marketing goals), which must be adhered to when managing the socio-economic system to ensure its permanent development. Certain goals are not imperatives in their content, but they are transformed into imperatives when a management decision states that they are mandatory. The transformation of goals into imperatives is conducted based on an appropriate mechanism, which is characterised by internal organisational system connections. At each hierarchical level of the management system, the overall goal turns into specific imperatives (categorical or hypothetical), which are based on various functionals, including marketing ones. Marketing imperatives, based on the dynamism of economic progress and goal-oriented principles of constancy, are tools for achieving the goal of the socio-economic system.

3. The need to imply the principle of marketing-imperative approach in the process of sustainable economic development is explained by the fact that, on 
the one hand, marketing imperatives form a "road map" for building and implementing a marketing strategy for individual businesses as local units of compliance and promotion of sustainable development using appropriate marketing technologies, on the other hand, they should be attributed to the fundamental principles of creating a general strategy for sustainable development of the national economy. The prospects for further research in this scientific area are the development of criteria for measuring, evaluating, and interpreting the effect of implementing marketing imperatives, followed by verification of the results obtained.

\section{REFERENCES}

[1] Cabinet of Ministers of Ukraine. (2021). National Economic Strategy until 2030. Retrieved from https://nes2030.org.ua/.

[2] Segeda, S.A. (2018). Methodological foundations of the category "development": The philosophical aspect. Economy and State, 10, 14-22.

[3] Kant, E. (1994). Critique of pure reason. Moscow: Mysl.

[4] Shevchenko, L.I. (Ed.). (2008). New dictionary of foreign words: About 40,000 words and phrases. Kyiv: Arius.

[5] Bilodid, I.K. (Ed.). (1970-1980). Dictionary of the Ukrainian language: In 11 volumes (Vol. 4). Kyiv: Naukova Dumka.

[6] Merriam-Webster. (2021). Retrieved from https://www.merriam-webster.com/dictionary/imperative.

[7] Gribinenko, O.M.(2018). Digitalization of the economy in a new paradigm of digital transformation. International relations. Series "Economic Sciences", 16, 35-37.

[8] Kolomiets, G.M., Melentsova, O.V., Shtuchny, V.G., \& Sushchenko, N.B. (2019). Transformations of marketing in a digital economy: Imperatives and obstacles. Business Inform, 9, 362-369.

[9] Svyatnenko,V.(2014). Marketing technologies as an instrument for efficient development of domestic enterprises. Bulletin of Taras Shevchenko National University of Kyiv. Economics, 8(161), 44-49.

[10] Ilina, M., \& Shpyliova, Y. (2017). Theoretic principles forming imperatives of a society's economic development. Economy and Society, 9, 221-226.

[11] Kovalchuk, M.V. (2014). The imperative of state economic safety: Institutional approach. Efficient Economy, 11. Retrieved from http://www.economy.nayka.com.ua/?op=1\&z=3574.

[12] Customer experience imperatives. (2021). Retrieved from https://www.merkleinc.com/thought-leadership/customerexperience-imperatives.

[13] Borysova, T.M., \& Monastyrskyi, H.L. (Eds.). (2020). Institutional principles and marketing imperatives of sustainable development. Ternopil: Ekonomichna dumka of WUNU.

[14] Tarasovych, L., Yaremova, M., Vlasenko, O., Shuliak, B., \& Kotova, L. (2021). Formation of marketing concept of rural economic development. In B. Alareeni, A. Hamdan, \& I. Elgedawy (Eds.), The importance of new technologies and entrepreneurship in business development: In the context of economic diversity in developing countries (pp. 445-453). Cham: Springer International Publishing. doi: 10.1007/978-3-030-69221-6 33.

[15] Zinchuk, T., Tarasovych, L., Yaremova, M., Usiuk, T., \& Kovalchuk, O. (2021). Participation and bridging: Involving etrepreneurs in the management of the EU rural economy. Estudios de Economía Aplicada, 39(5). doi: 10.25115/eea.v39i5.4900.

[16] Okhrimenko, A.G. (2017). Imperatives of development of the national tourist system. Scientific Bulletin of the International Humanities University. Series: Economics and Management, 23(1), 59-62.

[17] Frolova, L.V., \& Natorina,A.A.(2016). Imperatives of identification of marketing commodity strategy of the enterprise. Kryvyi Rih: Chernyavsky D.O.

[18] Khirivskyi, R., Cherevko, H., Yatsiv, I., Pasichnyk, T., Petryshyn, L., \& Kucher, L. (2020). Assessment and analysis of sustainability of the socio-economic development of amalgamated territorial communities of the region. European Journal of Sustainable Development, 9(2), 569-578. doi: 10.14207/ejsd.2020.v9n2p569.

[19] Borzenko, O.O. (2019). Structural deformations in the global financial markets after the 1990s. Vinnytsia: Tvory.

[20] Kovshova, I.O. (2018). Marketing management: Theory, methodology, practice. Kyiv: Vyshemirsky V.S.

[21] Julia, D. (2000). Philosophical Dictionary. Moscow: International Relationship.

[22] Usyuk, T.V. (2013). Institutional determinants of rural entrepreneurship. Marketing and Innovation Management, 4, 283-290.

[23] Laws, patterns and principles of management. (2020). Retrieved from https://pidru4niki.com/75104/menedzhment/ zakoni_zakonomirnosti_printsipi_menedzhmentu.

[24] Griffin, R., \& Pastey, M. (2006). International business. St. Petersburg: Peter.

[25] Churchwell, C.D. (2020). The new global business manager. Retrieved from https://www.begin.ru/articles/novyijglobalnyij-biznes-menedzher.html.

[26] Czinkota, M., Ronkainen, I., \& Tarrant, J. (1996). The global marketing imperative. Lincolnwood: NTC Publishing Group.

[27] Zinovchuk, V., \& Kopytova, I. (2018). A criteria model for assessing the efficiency of the production management. Management Theory and Studies for Rural Business and Infrastructure Development, 40(1), 118-127. doi: $10.15544 / \mathrm{mts} .2018 .11$. 
[28] Kravchenko, O., Kucher,A., Hełdak, M., Kucher, L., \& Wysmułek,J.(2020). Socioeconomic transformations in Ukraine towards the sustainable development of agriculture. Sustainability, 12(13), 5441. doi: 10.3390/su12135441.

[29] Skydan, O., Zinchuk, T., Nykolyuk, O., \& Voronych, M. (2021). Methodology for the assessment of geoeconomics potential of agriculture. Estudios de Economia Aplicada, 39(6). doi: 10.25115/eea.v39i6.5246.

[30] Capon, N. (2013). The virgin marketer. New York: Wessex.

[31] Capon, N., Kolchanov, V., \& McHulbert, J. (2010). Marketing management. St. Petersburg: Peter.

[32] Official website of the marketing agency Merkle. (n.d.). Retrieved from https://www.merkleinc.com/emea/who-we-are.

[33] Embrace the power of consumers. Welcome the revolution. (n.d.). Marketing imperatives. Hyper-personalization and the connected customer experience. Retrieved from https://www.merkleinc.com/emea/thought-leadership/ marketing-imperatives.

[34] Stadnyk, V., Izhevskiy, P., Khrushch, N., Sokoliuk, G., \& Tomalja, T. (2020). Strategic priorities of innovation and investment development of the Ukraine's economy industrial sector. In CEUR Workshop (pp. 145-166). Retrieved from http://ceur-ws.org/Nol-2713/paper12.pdf.

\title{
Когерентність маркетингових імперативів управління розвитком соціально-економічних систем
}

\section{Людмила Валеріївна Тарасович, Марина Іванівна Яремова}

\author{
Поліський національний університет \\ 10008, б-р Старий, 7, м. Житомир, Україна
}

\begin{abstract}
Анотація. Актуальний насьогодні процес переорієнтації існуючої моделі ринкової економіки на засади сталого розвитку супроводжується імплікацією маркетингової концепції управління соціально-економічними системами, технологія якої передбачає аргументацію визначених орієнтирів, яких необхідно дотримуватися. У контексті зазначеного когерентність маркетингових імперативів $\epsilon$ детермінантою забезпечення розвитку соціальноекономічних систем, а маркетингово-імперативний підхід варто вважати одним із важелів формування концепції сталого розвитку економіки. Метою наукового дослідження $\epsilon$ комплексне обгрунтування теоретико-методологічного змісту маркетингових імперативів, інтерпретації контурів їх когерентного впливу на процес управління розвитком соціально-економічних систем. Методологічною основою дослідження $\epsilon$ органічне поєднання загальнонаукових методів наукового пізнання на засадах системності із опрацюванням можливостей застосування специфічних методичних підходів до вирішення поставлених завдань та верифікації сформульованої гіпотези дослідження, зокрема монографічного, гіпотетичного передбачення, абстрактно-логічного, індукції та дедукції, історикоекономічного, порівняльного, трансформаційного, структурно-функціонального аналізу, абстрагування і контентаналізу, конструювання понять і категорій, графічного і табличного прийомів. У статті розкрито особливості еволюції етимологічної сутності імперативу за умов трансформацій соціально-економічних систем, обгрунтовано сутність маркетингових імперативів у світлі маркетингової ідеології, розроблено механізм трансформації цілей в імперативи у процесі досягнення мети соціально-економічної системи,доведено необхідність імплікації концепції маркетинговоімперативного підходу в процесі сталого розвитку економіки. Практична цінність проведеного дослідження полягає у науковому обгрунтуванні теоретико-методологічного змісту маркетингових імперативів, характеристиці іх когерентного впливу на управління розвитком соціально-економічних систем. Подальші дослідження націлені на розроблення критеріїв виміру, оцінки та інтерпретації ефекту імплементації маркетингових імперативів 3 подальшою апробацією отриманих результатів
\end{abstract}

Ключові слова: маркетинговий імператив, маркетингова концепція, маркетингова ціль, соціально-економічна система, управління розвитком, трансформація 